
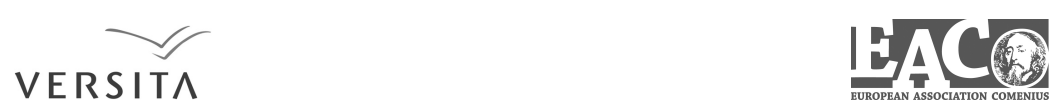

\title{
THE NEVER-ENDING FIGHT: ECONOMIC AND Political Corruption in Hungary
}

\author{
László Kőhhalmi ${ }^{1}$
}

\begin{abstract}
Every society must pay the "price of democracy" and in this price are "calculated" the rising number of crimes and the change in their quality, and also the unique alterations of corruption, among other things. The fight against economic-political corruption is a risky question, because the hunters and the hunted, those who conduct and those who undergo impeachment, are often members of the same political elite. It is in the interest of tax-payers that public funds should not become cash bribes, and furthermore that the rule of corruption should not grow dominant in even a single sphere. If we consider the moral weakness of politicians as the genesis of economic and political corruption, then the appropriate anti-corruption strategy would be the right combination of penalty policy and payment policy.
\end{abstract}

\section{Keywords}

Corruption, Price of Democracy, Lose their Legitimacy, Public Procurement, Penalty Policy

\section{Introduction}

\section{Fundamental ideas about the definition of economic and political corruption}

People talk a lot about political corruption on various television shows, and there are many scientific and educational papers written on the subject. ${ }^{2}$ Public interest in the issue is reflected by the Google search engine, which provides 801,000 results in Hungarian, and 11 million results in English for the term "political corruption". In spite of the large number of papers and analyses, we cannot say that it is a waste of time to examine the problem of political corruption in our country, judging it to already be lost in the past - on the contrary, there are few problems with a greater significance as far as today's politics are concerned.

\footnotetext{
${ }^{1}$ Faculty of Law, University of Pécs, 48-as tér 1, 7622 Pécs, Hungary. E-mail: kohalmi.laszlo@ ajk.pte.hu.

${ }^{2}$ Kránitz (1988).
} 
I determine political corruption - agreeing with András Sajó - to be corruption emerging in the functioning of the political system, namely, the betrayal of norms that serve public interest (public trust) in return for any kind of advantage.

The definition covers the following of such norms (for a certain advantage), where the behavior that follows the norm also violates public interest. That the advantage is directly personal for the "traitor" is not a condition for this. ${ }^{3}$

It must be admitted, however, that even defining "common weal" raises serious difficulties (and where are we so far in defining political corruption?). ${ }^{4}$ Can we equate common weal with GDP? To my mind, this is far from being the case. Common weal is not necessarily equal to a decision that is rational from an economic point of view.

In his classic work (Social traps - Diagnoses ${ }^{5}$ ), Elemér Hankiss quotes Edward Gibbon, according to whom political corruption is: "the most infallible symptom of constitutional liberty".

Lajos Szamel, in one of his papers that is rarely quoted today, explains that corruption originally meant the bribing of politicians and among them, statesmen only. ${ }^{6}$

According to László Lengyel, an overall trait of political corruption is that it has not changed throughout the ages. Characteristically, all governments make unbelievable efforts to cover up their own activities of corruption. ${ }^{7}$

László Korinek calls attention to the fact that the scope of the offences of corruption which is traditionally related to the workings of state and local government - includes more and more legal statements of facts, but such a criminal appellation (namely, "political corruption") is missing not only from the Hungarian, but from foreign penal codes as well. ${ }^{8}$ According to Joseph La Palombara, we can talk about political corruption when functionaries provide unlawful advantage in exchange for private benefit, thus failing in their duty of public function. ${ }^{9}$

Heidenheimer interprets political corruption as basically a relation of exchange that creates different relations of obligation (familial, patron-client, leader-follower, civic culture). ${ }^{10}$ According to C. Bicchieri and J. Duffy, political corruption is a phenomenon pervading both history and society. ${ }^{11}$

The intricate relations of political corruption is well-described by the so-called pyramid system of Tibor Sebestyén. This points out that, in the static system of corruption, those situated on the lower levels of the hierarchy bribe the ones on the higher levels of decision-

\footnotetext{
${ }^{3}$ Sajó (2001).

${ }^{4}$ Gulyás (2004).

${ }^{5}$ Hankiss (1983)

${ }^{6}$ Szamel (1989).

${ }^{7}$ Lengyel (2007).

${ }^{8}$ See Korinek (1010): "The collection of crimes of corruption is a practice, as in given statements of facts a significant characteristic of them appears either definitely and obviously (e. g. bribery), or in other cases not necessarily, but typically (e. g. abuse of authority): private benefit, or at least the aiming of consequences different from those according to the rules. Under such circumstances, it is not objectionable, in fact, it is quite useful from the viewpoint of cognition to sort and qualify the norms describing forbidden behaviour".

${ }^{9}$ LaPalombara (1994).

${ }^{10}$ Heidenheimer (1990).

${ }^{11}$ Bicchieri - Duffy (2004).
} 
making for the sake of having an illegal or unfair advantage; whereas in the dynamic system corruption starts from above, with people on the higher levels of hierarchy wanting something from the lower ones (e. g. maintaining clientele). ${ }^{12}$

Political corruption must be distinguished - in spite of the supposed similarity - from "everyday" corruption. Everyday (or small-time) corruption is when household or other personal providers are given a small gratuity, tip ${ }^{13}$, or when a traffic warden, policeman, official or other person of minor authority is given a bribe casually - in an envelope usually by a civilian. ${ }^{14}$

However, political corruption usually appears in a systematic fashion, mostly in the sense that it makes decisions that define and control a given system. So the term "systematic" does not necessarily mean something that is regular, but by all means is something that refers to the wicked nature of the whole political system.

Corruption appearing in the political system - with an expression from mountaineering - gets acclimatized fast and becomes immanent to the system itself. After appearing in the system, political corruption starts to proliferate and causes contraselection, economic setback, decline, and weakens the effectiveness of state and local government institutes. While a small-time criminal - excluding mental upset - usually causes "only" as much material damage as he or she stole (e.g. a stolen bicycle, pocket watch, etc.), the corrupt politician may cause negative effects to the state economy that even exceed the damage done by his or her corrupt activity, e.g. by planning a subway or a motorway in an irrational way.

Political corruption has a great damage multiplier, namely, the quotient of the indirect macroeconomic damage done in a long-term period to society and the amount of the unfair advantages directly obtained by the violators.

Political corruption can make state or local government investments more expensive by approximately 20-25 percent, and by our standard this could mean several hundred billion forints pulled out of the state economy. I do not think it is an overstatement to say that political corruption is one of the greatest challenges of our time. ${ }^{15}$

According to research carried out by Mária Vásárhelyi, public opinion - in its own system of norms - judges more harshly the corrupt politician than the corrupt official. The primary cause of this may be that people linked privatization to corruption from the first moment on (they became almost synonymous), and this had become more than evident by, e.g. the scandal of ÁPV Rt (State Privatization and Management of Property Co.) over premiums (the infamous Tocsik Case), in which what had previously been heard about was demonstrated, and maybe even personally experienced. ${ }^{16}$

\footnotetext{
12 Sebestyén (2009).

${ }^{13}$ Heidenheimer (1990) calls this "petty" corruption. Petty corruption is a "friendly" evasion of certain rules, for example, the slight distortion of facts, ignoring deadlines, using small tricks with parking tickets, etc.

${ }^{14}$ Sebestyén (2009).

${ }^{15}$ Kránitz (1993).

${ }^{16}$ According to research carried out by Vásárhelyi (1998), "two-thirds of the public today thinks that privatization is a hotbed of corruption, and every second adult citizen is of the opinion that privatization does not help, but worsens the economic status of Hungary".
} 
Political corruption may appear in several forms, such as:

- corruption between the public sphere and the political sphere,

- corruption between the private sector and the political sphere,

- corruption between politicians. ${ }^{17}$

In Hungary, undoubtedly one of the most "slippery", politically corrupted zones is the field between the private sector and the political sphere, and, furthermore, the strange and inscrutable world of public procurement.

It is the field between the private sector and the political sector that can obviously be recognised as one of the "most slippery" zones inflected by political corruption, and within this it is the strange and impenetrable world of public procurement that leads us into the world of economic corruption.

It is a specific solution of the Hungarian Penal Code still in force (until 30th June, 2013) that economic bribery and economic racketeering are committed by all those who carry out these crimes in their relations with non-officials. Thus it is not only the corruption committed by actors belonging exclusively to the economic scene, but also those belonging to the state (not including organisations of the public authority and the state administration) and social organisations and associations that can be found within the scope of economic corruption. ${ }^{18}$

It is important to emphasise this fact, as it is exclusively that corruption realized effectively within economic life, i.e. business corruption, that is meant by the term economic corruption in the leading countries of the European Union. It is incomprehensible for them that it can be derived from the Hungarian Penal Code in a causative way; namely, in the same way an academic professor can commit economic bribery as a passive party.

Business corruption, taken in the strict sense of the meaning, is interpreted in as many different ways worldwide as official corruption. An office is meant to be transparent, while business life is far from being transparent, even in its most primitive form. An example from Germany and Switzerland dating back to 2000 shows the lack of a deserved sentence in the case of business corruption: a "bribe" (commission given at /when contracting) was to be accounted as a factor for reducing the tax basis in the course of the deal and its fulfilment in Switzerland; this kind of tax was considered legal for a long period of time in Germany as well. ${ }^{19}$

Although undue advantage within economic life has never been considered neutral from either the legal or moral point of view, as it used to be in Germany (as a quasi-normal cost incurred in the course of doing business), it is a fact that its deprecation, both in criminal law and as an immoral act, is much milder than that aimed at the advantage gained by official persons.

Assessment within the framework of criminal law is obviously clear concerning the system of sanctions, on the basis of which it can be concluded that, from among the various forms of bribe it is the active economic bribe that is considered to be the least dangerous.

\footnotetext{
${ }^{17}$ Görgényi (2004).

${ }^{18}$ Kránitz (2005).

${ }^{19}$ Kránitz (2006).
} 
The moral assessment with regard to this is dual in Hungary, depending on the fact of whether the corrupt acts are carried out strictly by the actors in economic life between themselves (business corruption) or by those employed in social, cultural, educational and other spheres (a further segment of economic corruption).

It is the increment of the market economy that business corruption, taken in the strict sense of the meaning, causes a milder moral deprecation, as it is considered to be a personal affair by public opinion. ${ }^{20}$ Opinions concerning economic corruption outside business life are different, however. The independent internet portal http://halapenz.lap.hu (gratuity) is a good example in terms of user comments, which clearly show serious indignation on behalf of the general public. It is another peculiar example relevant to the present situation that there is no official gratuity available for physicians, i.e. doctors cannot ask patients for anything, as it would constitute a crime, but they can accept something after treatment (operation) without having to face any legal consequences, if a "gratuity after the fact" is allowed by the employer.

This kind of dual assessment is absolutely comprehensible and grounded even if there are billions of forints changing hands in business, while in the sphere of health care there are "only" tens of thousands of forints. The former simply "flies" above the radar of society - there is no information about it available; the latter, however, is cross-cutting.

It lies in the interest of the tax-payers that public funds should not become cash bribes, and furthermore that the laws of corruption should not grow dominant in even a single sphere.

\section{Problems of economic and political corruption}

The most comprehensive analysis of corruption in Hungarian specialized literature has been made by Mariann Kránitz, who found during her research that every society must pay the "price of democracy" and in this price is counted the rising number of crimes and the change of their quality, while the unique alterations of corruption are also "calculated", among other things. ${ }^{21}$

Political transformation in itself did not - could not! - abolish corruption, but reshaped it, changed its nature and direction. This is because corruption is very closely connected to the economic, political and social milieu in which it is realized. And furthermore: there are very few social phenomena that are so up-to-date, and which follow the changes of their milieu, as corruption. The ability to readily accommodate can be detected in the years during and after the political transformation of Hungary.

Consequently, the features of corruption - although its basic nature and essence did not change - were different before the transformation from what they are now, under the democratic system.

\footnotetext{
${ }^{20}$ Ibid.

${ }^{21}$ Ibid.
} 
While discussing political corruption, I would like to emphasize principally - and in my opinion this is the eternal "poisoned apple" status of this phenomenon - that it is a very effective way of solving problems and enforcing interests, and so it is very tempting for everyone.

When taking into account the few thousand years of the history of mankind, we cannot point to a single civilization without corruption, but of course we cannot resign from the pursuit of the dream of reaching such an ideal state. Furthermore, we do have convincing knowledge of communities which took the fight against political corruption seriously, and where the intensity of corruption thus clearly diminished.

Nevertheless, we must see that political corruption reacts to changes in legal circumstances in a very sensible way and immediately - like water, or light - finds its way through the cracks and activates itself, starting a whole avalanche of corrupt acts.

The problems are further deepened by the fact that political corruption has never really "respected" the borders of countries and continents. This phenomenon was probably one of the first (if not THE first) to be globalized. ${ }^{22}$

We can only successfully fight an unwanted phenomenon if we are familiar with the characteristics of the given phenomenon. The problem with political corruption is that there are too many "dark spots". However, there are two methods through which we can get a better and deeper understanding of the phenomenon and its workings: one of them is the corruption-perceptions index created by the international organization Transparency International, the other is the collection of information on criminal statistics.

The international civil organization fighting against corruption, the Berlin-based Transparency International, creates and publishes the Corruption Perceptions Index or CPI of individual countries at the same time. The index creates the countries' rank of corruption by weighting, which is based on studies published by independent economic and financial organizations. ${ }^{23}$ The scoring (the weighting) happens on a scale from one to a hundred, where a fully corruption-clear country could receive hundred points, although such a country has so far never been found in the history of CPIs. (In 2012, for example, first place was taken by the least corruption-ridden Denmark, Finland and New Zealand, with 90 points, while Afghanistan, (North) Korea and Somalia finished last with 8 points each. $)^{24}$

But the Perceptions Index is, due to its subjective nature, "only" capable of providing certain guidelines regarding contamination in each country. A subjective scale is not really appropriate for the analysis of such an objective phenomenon as corruption, which is closely connected to the fragments of economy, bureaucracy and authority.

Also, the CPI induces a "labeling effect", in that it puts either a positive or a negative label on the given country. Furthermore, this labeling itself works as a generative factor. A country with a small level of corruption will be even clearer, and a country contaminated with corruption will become even more corrupt.

\footnotetext{
${ }^{22}$ Kránitz (2005).

${ }^{23}$ Ibid.

${ }^{24}$ Transparency International (2012) (see http://cpi.transparency.org/cpi2012/results/).
} 
The CPI is an internationally accepted standard, but can provide strongly questionable results and consequences as far as the judgment of a given country's state of corruption is concerned. ${ }^{25}$

But according to information from criminal statistics, we should consider political corruption a rarity in our criminology. This is obviously a false diagnosis because of latency, as, due to the unity of interest between the provider and receiver of the unfair advantage, very few criminal procedures are initiated because of activities of corruption. (E.g. Zoltán Székely, previously a Member of Parliament, asked for a bribe of 20 million forints $\approx$ 66,700 euro, but got a legally binding sentence of 6 years in prison and a secondary financial punishment of 9 million forints instead.)

The low number ${ }^{26}$ of criminal procedures can be explained by the fact that most of these procedures start after a civil denouncement - as László Korinek found out during his latency research ${ }^{27}$ : "the citizen is the eye of law" - and in case of political corruption, the willingness to denounce is extremely low. ${ }^{28}$

Mariann Kránitz even called the statistics referring to the rate of corruption cases and their relation to the whole number of criminal cases tragicomical. ${ }^{29}$

Even if we "add up" our knowledge of political corruption gained from the Perceptions Index and criminal statistics, we cannot say that we are familiar with the whole spectrum of political corruption.

One of the crucial problems of corruption in Hungary comes from the malfunction of our economic system. As previously in socialism the lack of products and services caused corruption, today overproduction is the "mainspring". Most market members would be glad to sell services to the state and local government sector. In this case, a small present (e.g. a bonus holiday) to the mayor or a Member of Parliament makes it easier to choose one company or the other. And we must admit that the system of public procurement is a dead-end, I would even go so far as to say that, at the time of "freehand purchase", public money had been spent in a much more favourable way than today.

Public procurements and investments and those of the municipalities play an outstanding role in the Hungarian economic life. This situation is further enhanced by the global economic crisis.

The majority of the orders of the state and the municipalities take place in the frame of public procurements (except for: investments related to national security and the national economy).

Cases of misuse in connection with public procurements cannot have been solved either by previous law or the Public Procurement Act in force (Act CVIII of 2011 on Public Procurement).

\footnotetext{
25 Kránitz (2005).

${ }^{26}$ See Korinek (2010): "Because of the rather high latency of crimes of corruption, one must accept the fact regarding the methodology of research that there are serious obstacles in the way of direct cognition. Thus the reflection of the phenomenon - which happens in a particular circle and way-gets an emphasis during scientific work."

${ }^{27}$ Korinek (2006).

${ }^{28}$ Gál (2007).

${ }^{29}$ Kránitz (2005).
} 
There are two major groups into which misuses concerning public procurements are to be divided. One of them is when the public procurement act is simply being neglected and contracts are entered into by circumventing it. There are probably several and various kinds of purposes; however, it is obvious even to outsiders, having only cursory knowledge about it, that gaining profit - even with the help of corruption - is among the main purposes. ${ }^{30}$ The other big group is made up from those misuses when the "wording" of the act is being complied with but its real essence is being neglected.

The simplest example of this is the so called restricted tendering procedure, in which all three tenderers have to compete to gain the business. It actually does work formally in everyday life, but in a peculiar way. It has been given the well deserved name "get two losers" - public procurement in economic jargon. Very often there is only one actual tenderer interested in the realization of the business and this interested party takes care of the pretence-participation of the other two tenderers - very often for some extra benefit. ${ }^{31}$ Misuses in connection with the invitation to tenders are not rare either. In such cases, the writer of the tender can impose conditions concerning the capital strength, the tender guarantees and other aspects of the tendering firms which can be fulfilled only by one particular group of entrepreneurs or just one tenderer. The relations are obvious but it is impossible to trace the movement of the bribe money.

As it is the "market of the purchasers" that dominates the conditions of the market economy and because the orders by the state and the municipalities provide the safest business, the circle of entrepreneurs playing a determining role in state and municipality tenders such as winning these tenders is clearly to be circumscribed.

Of course, firms use other names when applying for a tender but the circle of owners is more or less the same and the bigger firms very often roll over the smaller ones in the smaller market because:

- they have influence in the political sphere and they start with a dominant position in the processes preferred by them,

- they win the large investments as main contractors or general contractors and then drive down the costs involving small- and medium-sized enterprises,

- if they retard the payments of invoices, they may drive small enterprises into bankruptcy.

Entrepreneurs having lost the tender are entitled to apply to the Arbitration Board for Public Tenders (Közbeszerzési Döntóbizottság); however, the number of those using legal remedy is relatively low when compared with the number of procurement processes. This can be explained by two causes: if the losing entrepreneur is already known and disposes of well-established connections, he or she has good reasons to expect to win the next time. $\mathrm{He}$ or she does not intend to endanger their good connections because of a process of legal remedy, even in the event that he or she is in the possession of exact information concerning the infringement or corruption.

\footnotetext{
${ }^{30}$ Kránitz (2006).

${ }^{31}$ Ibid.
} 
If the losing entrepreneur is unknown and has no connections, he might make use of legal remedy. He might be agreed with and the writer of the tender will be found by court to be in default. This will not result in any substantive changes, as while the case is being examined by the arbitration board, the writer of the tender has already entered into a contract with a certain firm and the contract is no longer to be annulled. "An entrepreneur roistering will not be let go even as far as the threshold" - this is the opinion of Kránitz, Mariann ${ }^{32}$ about this issue.

The bulk of cases of economic bribes, however, are not connected to the invitation to tender. The general practice of corruption is embodied in such a way that entrepreneurs winning the tender "recycle" a certain percentage of the investment cost of the tender received to the orderer. It is a worldwide experience that this sum is on average $5 \%$ of the net value, which means a considerable sum in the case of orders/tenders of several billions of forints.

Economic corruption, as a result of the process of public tenders, actually makes economic life more expensive, since corruption items are a priori built into the price by the entrepreneurs. Entrepreneurs that fail to do so (i.e. those who make a cheaper offer than those who are forward-looking) may go down or do not provide the required quality (because of using cheaper basic materials, employing cheaper manpower or simply doing a poor job), or finally manage to reach higher prices by adding nominal "extra" jobs.

Situations of corruption taking place within the banking system represent a mysterious field of corruption appearing in economic life.

Earlier, one could read about the existence of the so-called stripped bank loans in the relevant literature, the point of which was that the borrower leaves a certain percentage of the claimed and effectively used loan a priori. He has a repayment obligation of the whole sum, the quota left in the bank is the undue advantage provided by him. The net lending "commission" - this certain percentage - corresponds to one tenth of the loan, but according to some experts it may be as high as 15-20\%.

The banking world represents a closed system. It seems that the notion of banking secrecy is interpreted in a relatively wide sense, as corrupt employees are reported very rarely. Thus, information on the practice of the stripped bank loans is delivered mainly from the group of the active bribers, who do not press charges in criminal proceedings out of self-interest. One can probably find a series of bribes in the background of criminal matters against bank employees because of misappropriation, but it cannot be proved mutatis mutandis.

The small number of criminal proceedings - for this reason statistically not relevant started because of mismanagement or misappropriation and is not likely to represent the actual happenings.

It looks like our politicians are again and again tempted by the financial possibilities offered by the real estate business. In the days of councils, the "out of turn" apportion of a flat, and today, the underselling of a state or local government real estate can feed the bank account of corrupt politicians. Real estate "on the periphery" can suddenly be

${ }^{32}$ Ibid. 
qualified as an inner city area by the local government, the previously worthless site becomes a building site, and this is quite a bargain for the insiders. The local government can easily be seen through, when it accepts an expert's opinion on one of its own estates, and receives a detailed justification of the worthlessness of that local government estate and the necessity of it being immediately sold.

\section{The criminal de lege lata regulation of economic-political corruption}

The legislators of Hungary deal with delinquencies of corruption in the same chapter of violations against public life as with crimes against polity and jurisdiction.

One must pay special attention to these delinquencies since it is a basic question of importance for every society that the functionaries, the members of the social-economic and political life, - the legitimate leaders of a community - do their tasks without predilection. This determines the trust of citizens in the different state and local government organizations, and their opinion about the political and social system.

According to the Minister's Preamble to the Penal Code, the provisions of the legal statements of facts that are aimed at corrupt behavior "protect first and foremost the trust invested in the lawful, unbiased and impartial workings of state authorities, officials and people of other important social function. The so-called crimes of corruption (bribery and profiteering from power) endanger this trust, and the purity of public life in general, and those strict moral and social requirements that should be effective not only in the workings of authorities and officials, but in the economic and cultural life as well". 33

Considering that the crimes of corruption have such a significant demoralizing effect in politics, fifteen paragraphs of law deal with crimes against the purity of public life.

Crimes against the purity of public life are dealt with in the following:

- Bribery Penal Code 250-255/A. , $^{34}$

- Misprision of Bribery 255/B. $\S$,

- Influence Peddling 256. ${ }^{35}$

\footnotetext{
${ }^{33}$ Minister's Preamble to the Penal Code.

${ }^{34}$ Act IV of 1978 on the Criminal Code Section 250. Bribery "(1) Any public official who requests an unlawful advantage in connection with his actions in an official capacity, or accepts such advantage or a promise thereof, or agrees with the party requesting or accepting the advantage, is guilty of a felony punishable by imprisonment between one to five years. (2) The punishment shall be imprisonment between two to eight years if the act of crime is committed: a) by a public official in a high office, or by one vested with competence in affairs of key importance; b) by another public official in matters of great importance. (3) The perpetrator shall be punished by imprisonment between two to eight years, or between five to ten years in accordance with the distinction contained in Subsections (1) and (2), if he breaches his official duty in exchange for unlawful advantage, exceeds his competence or otherwise abuses his official position, or if he commits the act in criminal conspiracy or in a pattern of business operation".

${ }^{35}$ Act IV of 1978 on the Criminal Code Section 256. Influence Peddling "(1) Any person who - purporting to influence a public official - requests or accepts an unlawful advantage for himself or on behalf of another person is guilty of a felony punishable by imprisonment between one to five years. (2) The punishment shall be imprisonment between two to eight years if the perpetrator: a) purports to or pretends that he is bribing a public official; b) pretends to be a public official; c) commits the crime in a pattern of business operation. (3) Any person who commits the crime defined in Subsection (1): a) in connection with an employee or member of an economic
} 
- Persecution of a Person Making a Notice of Public Concern 257. $\S .{ }^{36}$

Crimes against the purity of international public life are dealt with in the following:

- Bribery in International Relations 258/B-258/D. $\oint$,

- Influence Peddling in International Relations 258/E. $\oint$,

- Misprision of Bribery in International Relations 258/F.§.

In my opinion, the Hungarian Penal Code has quite serious sanctions (a maximum of ten years imprisonment in certain cases) for the perpetrators of crimes of corruption and also the court judgment practice is to sentence the recipient of even a few ten thousand forints of bribe to a term of imprisonment that is to be enforced by all means.

According to an interesting suggestion by Mihály Tóth, the exaggerated and unrealistic sanctions may have an opposite effect: if part of the legal norms is impossible to adhere to, then law-abiding behavior is questioned elsewhere as well. ${ }^{37}$

A new era of the fight against economic and political corruption may start in Hungary as the new Hungarian Penal code, namely Act C of 2012 of the Penal Code, will come into force on 1st July, 2013.

The new Penal Code simplifies the facts of the case structurally and thus regulates crimes against the morality of public life and the morality of international public life in one capital, as opposed to the earlier two independent capitals.

The criminal conduct of crimes against the morality of international public life is equal to the facts of the case in the corresponding crime against the morality of public life and the custodial sentences are also the same. Accordingly, the law, where necessary on the grounds of international treaties or the acts of the European Union, refers to the fact at the end of the given fact of the case in a separate paragraph that the act regulated there is to be punished in relation to an international official person.

The law defines the sequence of the single facts of the case based on a consequent logic concerning the speciality within the protected object of law (economic sphere, administrative sphere, proceedings by authorities) and the measure of the sanction which can be imposed.

It is one of the most essential changes of the act as compared to the regulation in force that the act allows for the reduction of the sentence or its non-imposition instead of the termination of the reasons of the criminality in the case of the perpetrators that are willing to cooperate with the authorities in the detection of acts of bribery.

operator or non-governmental organization is guilty of a misdemeanor punishable by imprisonment for up to two years; b) in connection with an employee or member who is authorized to act in the name and on behalf of an economic operator or non-governmental organization is guilty of a felony punishable by imprisonment for up to three years. (4) Any person who commits the crime defined in Subsection (3) in a pattern of business operation is guilty of a felony punishable by imprisonment for up to three years, or between one to five years, as consistent with the categories specified therein".

${ }^{36}$ Act IV of 1978 on the Criminal Code Section 255/B Persecution of a Person Making a Notice of Public Concern "Any person who takes any detrimental action against a person who has made an announcement of public concern is guilty of a misdemeanor punishable by imprisonment for up to two years".

37 Tóth (2010). 
Active repentance does not automatically mean exemption from punishment according to the new act but depends on the decision of the court, allowing for suitable leeway for courts when considering individual circumstances.

\section{Conclusion}

\section{Means of criminal legislation in the fight against economic-political corruption}

The fight against political corruption is a somewhat risky question, because the hunters and the hunted, those who conduct and those who undergo impeachment are often members of the same political elite. People of political power punish other people with political power, so this can easily turn into a "family issue", which can in turn affect the efficiency of the fight against corruption.

According to Gyula Gulyás, fighting against political corruption is rendered more difficult by the people's ambivalent feelings toward politics: on the one hand, they regard political corruption as an elemental part of the political system, on the other, they protest against it with all their might. ${ }^{38}$

The phenomena of corruption are not obvious, and neither is the way they are legally judged. Does that Member of Parliament have criminal responsibility who, in the case of an investment of several billion forints, enforces the interests of his or her own voting district as opposed to the interests of the whole country?

The fight against political corruption depends on the context: it depends on the balance of forces within the elite, the relation between the elite and the society or whether the strategies against corruption are probably going to be only specious solutions or substantive measures.

Those politicians who declare war on corruption need not only the support of the law, but also a moral legitimacy to be successful in their fight against corruption. ${ }^{39}$ But politicians advertising zero corruption can easily become the prisoners of their own promises, and lose their legitimacy quickly and irreversibly.

According to Gyula Gulyás, anti-corruption policies depend on the governments' decisions:

- what they consider the cause of corruption,

- how they judge its social consequences,

- how determined is the government in abolishing political corruption. ${ }^{40}$

If we consider the moral weakness of politicians as the genesis of political corruption, then the appropriate anti-corruption strategy should be the right combination of penalty policy and payment policy.

\footnotetext{
${ }^{38}$ Gulyás (2004).

${ }^{39}$ Ibid. It is worth mentioning that, as "flagships" in the war against political corruption, R. Gandhi, in the election campaign of 1984, or President Lopez Portillo between 1976 and 1982, established their future political careers.

${ }^{40}$ Ibid.
} 
On the one hand, this can lead to the introduction of a system of highly severe sanctions on the activities of corrupt politicians, e.g. criminal laws that allow the sentencing of ten or more years of imprisonment.

On the other hand, it can mean the raising of politicians' wages. As long as payment (e.g. royalty, official allowance) to politicians (and I mean by this professional or "semiprofessional" politicians) for their service amounts to only a "supplementary income" and is not enough for a living, the politician shall try to solve the dilemma of either serving the public and not being able to earn enough money for himself; or making enough money and considering public matters only occasionally.

Then again, we must know that the fight against corruption has an economically rational optimality as well. If the state (for example, Singapore) pays too much to its politicians (e.g. all members of local governments were to receive a monthly royalty of 2 million forints $\approx 6,600$ euro), then the resulting state expense could exceed the damages done by political corruption, so - from an economic point of view - the state should rather undertake to damage corruption than provide extra allowances for politicians.

In connection with the fight against corruption, the representatives of different disciplines have provided many ideas in accordance with the field they were working on. As a representative of criminology, I would like to provide a few suggestions and opinions below:

- For the fight against corruption to be successful, we first need a simpler law-system. The obsolete and outdated laws need revision, and wrong laws must be filtered out. Legislation should be simplified, and we must prevent any form of Lex Imperfecta. Laws should be used not to hinder, but to help both the participants of the economy and the citizens as well. ${ }^{41}$

- The ultima ratio role of criminal law. Regarding corruption, the role of criminal law sanctions should be neither under- nor overrated. It is not the role and task of criminal law to solve the problems of social and political life. Unfortunately, in Hungary, there has been a tradition of the government trying to solve the dysfunction of society with the help of criminal law since the political transformation. In the field of political corruption, the problems are basically not of a penal nature, but are connected to other branches of law altogether. ${ }^{42}$ The legislator cannot resign from influencing political corruption by means of criminal law, but the main line of bearing should be the use of social - and not penal - tools. Criminal law as an ultima ratio can only be effective if it is supported by a wide selection of tools and methods for suppression and prevention. ${ }^{43}$

- Utilization of the possibilities of witness protection in a better way. In cases of political corruption, there are such people (e.g. secretaries, drivers) who could be key witnesses, as they have information on all the daily businesses of certain politicians, but their possibilities of livelihood are limited. If those people who provide information on political corruption could participate in a witness protection

\footnotetext{
${ }^{41}$ Kránitz (2006).

${ }^{42}$ Márki (2010).

${ }^{43}$ Kránitz (2005).
} 
program, the "willingness to bear witness" would probably be higher, and witness memory would largely improve. But with regard to witness protection we must point out that the present regulation system should be improved, as the level of salary provided by the state to a relocated witness with a new identity is not too tempting.

Witness protection is often connected to the use of plea bargain, and to the case when the legislator is trying to break the consensus of will and interest between the parties involved in political corruption with the opportunity to plead guilty and the promise of impunity [Penal Code 255/A.§].

- The world of the delinquencies of political corruption is usually known for conspiracies, communication through intermediary channels, speech and messages of an "encoded" (ciphered) nature (e.g. lobby-money, soap, cookie, club of beneficiary entrepreneurs). In order to improve the results of retracing corruption one cannot forget about the use of undercover investigators and secret service methods.

- From time to time, the claim surfaces among both professionals of theory and practice that in cases of delinquencies of political corruption, special rules of verification should be applied to the presumed perpetrators. The so-called reversion of the burden of proof, as a novum of criminal procedure would mean that the accused should prove the legal origin of the assets coming from corruption, and if he or she would be unable to do that - e.g. the assets are not backed up by income subject to tax or tariffs - then it would mean an incriminating circumstance (fact) for him or her.

In my opinion, the revision of the burden of proof can lead to serious abuse of the power to punish by the authorities - e.g. the moral liquidation of political opponents - and thus this is by all means an innovation that should be rejected.

- A suggestion is raised from time to time by the government in power that an independent authority / office (e.g. Office for the Protection of Public Order, AntiCorruption Office) should be established for the fight against corruption. In my opinion, this is a faulty and unprofessional notion. In Hungary the prosecution can cover this area well, it is unnecessary to double the organizational system of the fight against corruption, as in certain cases this could lead to a clash between scopes of authority, to loss of information and to a war of prestige (rivalry) between authorities.

- Joining international and European penal treaties and provisions against (political) corruption as soon as possible, and adjusting the Hungarian substantive, procedural and executive laws to international standards. ${ }^{44}$

Summarizing my thoughts about political corruption, I can say that the viewpoint that presents most politicians as soulless creatures filling their own pockets with money is false, as this is prevented by many legal means (e.g. declaration of property). The election campaigns obviously want to create political advantage from the existence of economicpolitical corruption, but this is only a technique of political marketing to gain more votes.

44 Végvári (2001), Végvári (2008). 
But it is also true that a jeans-wearing representative can sometimes become a plutocrat in no time and this is not the world of coincidences (and lottery jackpots).

The fight against economic-political corruption seems to be an unending war and success will come only after a long, long time.

\section{References}

Bicchieri, C., Duffy, J. (1997). Corruption Cycles. Political Studies, XLV, 477-495.

Gál, I. L. (2007). Gazdasági büntetójog közgazdászoknak [Economic Criminal Law for Economists]. Akadémiai Kiadó. Budapest.

Korinek, L. (2006). A bûnözés visszatükröződése. Latens bûnözés, bûnözésábrázolás, félelem a búnözéstől [Reflections of Crime. Latency, Portrayal and Fear of Crime]. In Gönczöl, K., Kerezsi, K., Korinek, L., Lévay, M. (eds.). Kriminológia-Szakkriminológia [Criminology - Specialized Criminology]. Budapest: Complex Kiadó Jogi és Üzleti Tartalomszolgáltató Kft.

Görgényi, I. (2004). Az Európai Unió elvárásai a vesztegetés kriminalizálása terén a kerethatározat előtt és után [Expectations of the European Union on the Field of the Crime of Corruption Before and After the Framework Decision]. In Gellér, B. (ed.). Györgyi Kálmán Ünnepi Kötet. Budapest: KJK-Kerszöv Jogi és Üzleti Kiadó Kft.

Gulyás, Gy. (2004). A politikai korrupcióról [On Political Corruption]. In Gulyás, Gy. Politikai korrupció [Political Corruption]. Budapest: AULA Kiadó.

Hankiss, E. (1983). Társadalmi csapdák-Diagnózisok [Social Traps - Diagnoses]. Budapest: Magvető Kiadó.

Heidenheimer, A. J. (1990) Perspectives on the Perception of Corruption. In Heidenheimer A. J., Johnston. M., LeVine V. T. Political Corruption, A Handbook. New Brunswick and London. Transaction Publishers.

Korinek, L. (2010). A korrupció legfontosabb kriminológiai összefüggései. [The Main Criminological Bearings of Corruption]. In Csefkó, F., Horváth, Cs. (eds.). Politika és korrupció-A törvényesség és a törvénytelenség határai. [Politics and Corruption - Limits of Lawfulness and Unlawfulness]. Pécs: Pécsi Tudományegyetem Állam-és Jogtudományi Kar, Pécs-Baranyai Értelmiségi Egyesület.

Kránitz, M. (1988). A korrupciós bünözés [Crimes of Corruption]. Budapest: Közgazdasági és Jogi Könyvkiadó.

Kránitz, M. (1993). Korrupció a világban - internacionális korrupció [Corruption in the World - International Corruption.] In (eds.) Pusztai, L. Kriminológiai és Kriminalisztikai Évkönyv [Yearbook of Criminology and Forensic Science]. Budapest: IKVA.

Kránitz, M. (2005). A korrupció utolsó huszonöt éve Magyarországon [The Past TwentyFive Years of Corruption in Hungary] (unpublished essay).

Kránitz, M. (2006.) A korrupció utolsó huszonöt éve Magyarországon [The Past TwentyFive Years of Corruption in Hungary] (posthumous essay). Ügyészek Lapja [Journal of Prosecutors], 5.

LaPalombara, J. (1994). Structural and Institutional Aspects of Corruption. Social Research, LXI, 2. 
Lengyel, L. (2007). A politikai korrupció kérdéséhez [Questions of Political Corruption]. In: A korrupció elleni küzdelem jogi és szervezeti eszközei [The Legal and Organisational Means of Fighting Corruption]. Budapest: Emberi Jogok Magyar Központja Közalapítvány.

Márki, Z. (2001). Válasz a korrupciós kihívásokra [Answering the challenges of corruption]. In Csefkó, F., Horváth, Cs. (eds.). Korrupció Magyarországon [Corruption in Hungary]. Pécs: Pécs-Baranyai Értelmiségi Egyesület - Pécsi Tudományegyetem Állam-és Jogtudományi Kara.

Sajó, A. (2001). A vesztegethető államtól a zsaroló államig [From the Corrupt State to the Extortion State]. Mozgó Világ, 07.

Sebestyén, T. (2009). A politikai korrupció piramisa és kármultiplikátora [The Pyramid and Damage-Multiplier of Political Corruption]. Polgári Szemle [Civil Review], V(6).

Szamel, L. (1989). A korrupció, a protekció és a többi ... [Corruption, Protection and So On ... ]. Budapest: Kossuth Könyvkiadó.

Tóth, M. (2010). Adalékok a kriminális korrupció megítélésének néhány újabb kérdéséhez. [On Some New Questions of the Evaluation of Criminal Corruption]. In Csefkó, F., Horváth, Cs. (eds.). Politika és korrupció - A törvényesség és a törvénytelenség határai [Politics and Corruption - Limits of Lawfulness and Unlawfulness]. Pécs: Pécsi Tudományegyetem Állam-és Jogtudományi Kar, Pécs-Baranyai Értelmiségi Egyesület. Transparency International (2012). Corruption Perceptions Index 2012. Retrieved March 11, 2013 from http://cpi.transparency.org/cpi2012/results/.

Vásárhelyi, M. (1998). A korrupció a közgondolkodásban [Corruption in Public Thinking]. Szociológiai Szemle [Review of Sociology], 4.

Végvári, R. (2001). Nemzetközi fellépés a korrupció ellen [International Fight against Corruption]. Állam-és Jogtudomány [State and Law Science], XLII, 1-2.

Végvári, R. (2008). Vesztegetés [Bribery]. In Kondorosi, F., Ligeti, K. (eds.) Az európai büntetójog kézikönyve [Handbook of the European Criminal Law]. Budapest: Magyar Közlöny lap-és Könyvkiadó. 